\title{
Approaches for High-Efficiency III-V/Si Tandem Solar Cells
}

\section{Masafumi Yamaguchi ${ }^{*}$, Kan-Hua Lee ${ }^{1}$, Patrick Schygulla², Frank Dimroth ${ }^{2}$, Tatsuya Takamoto ${ }^{3}$, Ryo Ozaki', Kyotaro Nakamura'1, Nobuaki Kojima1, Yoshio Ohshita1}

\author{
${ }^{1}$ Toyota Technological Institute, Nagoya, Japan \\ ${ }^{2}$ Fraunhofer Institute for Solar Energy System, Freiburg, Germany \\ ${ }^{3}$ Sharp Corporation, Nara, Japan \\ Email: *masafumi@toyota-ti.ac.jp
}

How to cite this paper: Yamaguchi, M. Lee, K.-H., Schygulla, P., Dimroth, F., Takamoto, T., Ozaki, R., Nakamura, K., Kojima, N. and Ohshita, Y. (2021) Approaches for High-Efficiency III-V/Si Tandem Solar Cells. Energy and Power Engineering, 13, 413-427.

https://doi.org/10.4236/epe.2021.1312029

Received: November 16, 2021

Accepted: December 14, 2021

Published: December 17, 2021

Copyright $\odot 2021$ by author(s) and Scientific Research Publishing Inc. This work is licensed under the Creative Commons Attribution International License (CC BY 4.0).

http://creativecommons.org/licenses/by/4.0/

\begin{abstract}
The Si tandem solar cells are very attractive for realizing high efficiency and low cost. This paper overviews current status of III-V/Si tandem solar cells including our results. The analytical results for efficiency potential of Si tandem solar cells and loss analysis of Si bottom cells as well as bandgap energy optimization of sub-cells are presented. The 2-junction and 3-junction $\mathrm{Si}$ tandem solar cells have potential efficiencies of $36 \%$ and $42 \%$, respectively. ERE (external radiative efficiency) analysis for Si solar cells is analyzed in order to clarify properties of Si bottom solar cells. Properties of single-crystalline Si heterojunction solar cell fabricated in this study were analyzed. The current status of efficiencies of our Si bottom cell, upper III-V 2-junction solar cell and III-V/Si 3-junction tandem solar cell was shown to be $5.2 \%$ and $28.6 \%$ and $33.8 \%$. Achievement of $J_{s c}$ of $12 \mathrm{~mA} / \mathrm{cm}^{2}$ for Si bottom cell is necessary to realize high-efficiency 3 -junction Si tandem solar cells with an efficiency of more than 37\%. In addition, this paper presents ERE analysis of III-V 2-junction upper solar cells for improving III-V/Si 3-junction tandem solar cells. Several ways to improve efficiency of III-V/Si 3-junction tandem solar cells by reducing non-radiative recombination, optical and resistance losses are shown.
\end{abstract}

\section{Keywords}

High-Efficiency, Solar Cells, Si Tandem, Multi-Junction, Efficiency Analysis

\section{Introduction}

The development of high-performance solar cells offers a promising pathway toward achieving high power per unit cost for many applications. Especially, 
photovoltaic-powered vehicles [1] [2] [3] are very useful for reducing $\mathrm{CO}_{2}$ emission of vehicles. The authors have shown that vehicles powered by high-efficiency solar cell modules with an efficiency of more than $35 \%$ have potential of driving distance of more than $30 \mathrm{~km} /$ day on average and more than $50 \mathrm{~km} /$ day on a clear day [3]. In addition, the authors have shown that vehicles powered by high-efficiency solar cell modules are very effective for reduction in $\mathrm{CO}_{2}$ emission of vehicles and charging cost saving of electric vehicles [3].

However, as state-of-the-art single-junction solar cells are approaching the Shockley-Queisser limit [4], so-called multi-junction [5] approach can efficient photon absorption. Although 39.5\% efficiency has been achieved with GaInP/ GaAs-multi-quantum well/GaInAs 3-junction solar cell by NREL [6], significant cost reduction is necessary. According to our [1] [7] and NREL's [8] [9] cost analysis for III-V compound tandem solar cells, the Si tandem solar cells are shown to have possible way for cost reduction of III-V compound tandem solar cells in addition to high-speed growth method and concentrator operation. The Si tandem solar cells [9]-[14] by integration of Si with III-V, II-VI, chalcopyrite and perovskite are very attractive for realizing high-efficiency and low-cost. Although high-efficiency $\mathrm{Si}$ tandem solar cells with an efficiency of $35.9 \%$ have been demonstrated by Essig et al. [9] and Schygulla et al. [14], loss analysis of sub-cells is very important in order to realize further higher efficiency Si tandem solar cells.

This paper shows analytical results for efficiency potential of Si tandem solar cells and loss analysis of Si bottom cells as well as bandgap energy optimization of sub-cells. The 2-junction and 3-junction Si tandem solar cells have potential efficiencies of $36 \%$ and $42 \%$, respectively. The ways to realize such high-efficiency Si tandem solar cells are presented. For Si bottom solar cells, improving external radiative efficiency (ERE) of Si solar cells is shown to be very important. The effects of illumination intensity upon the properties of Si solar cells are analyzed in order to clarify properties of Si bottom solar cells. Achievement of $J_{s c}$ of 12 $\mathrm{mA} / \mathrm{cm}^{2}$ for Si bottom cell is necessary to realize high-efficiency 3-junction $\mathrm{Si}$ tandem solar cells with an efficiency of more than $37 \%$. In addition, this paper suggests that improvements in saturation current density and shunt resistance of Si bottom cells, optimization of bandgap energy of sub-cells are essential for developing high-efficiency Si tandem solar cells. For upper III-V 2-junction solar cells, improving ERE by reducing non-radiative recombination is shown to be very important. Several ways to improve efficiency of III-V/Si 3-junctuon tandem solar cells are shown. Finally, The III-V/Si 3-junction tandem solar cells are shown to have practically achievable efficiency of more than $40 \%$ by improving properties of Si bottom cell and III-V 2-junction solar cell.

In Section 3, approaches for realizing high-efficiency III-V/Si tandem solar cells are shown based on analytical procedure for estimating efficiency potential of Si tandem solar cells described in Section 2. In Section 4, ways for efficiency improvements of III-V/Si 3-junction solar cells are discussed. 


\section{Analysis for High-Efficiency Potential of Si Tandem Solar Cells}

In order to clarify high-efficiency potential of Si tandem solar cells, efficiency potential of Si tandem solar cells was calculated by estimating the ERE (external radiative efficiency) of solar cells from open-circuit voltage $V_{o c}$ [15]-[20]:

$$
V_{o c}=V_{o c: r a d}+(k T / q) \ln (\mathrm{ERE}) \text {, }
$$

In the case of multi-junction tandem solar cells, we defined average ERE $\left(\mathrm{ERE}_{\text {ave }}\right)$ by using average $V_{o c}$ loss:

$$
\sum\left(V_{o c, n}-V_{o c, r a d, n}\right) / n=(k T / q) \ln \left(\mathrm{ERE}_{\mathrm{ave}}\right),
$$

The resistance loss of a solar cell was estimated solely from the measured fill factor and the ideal fill factor $\mathrm{FF}_{0}[21]$ :

$$
\mathrm{FF} \approx \mathrm{FF}_{0}\left(1-r_{s}\right)\left(1-r_{s h}^{-1}\right) \approx \mathrm{FF}_{0}\left(1-r_{s}-r_{s h}^{-1}\right)=\mathrm{FF}_{0}(1-r),
$$

Details of analytical procedure are shown in our previous papers [18] [19] [20].

Figure 1 shows calculated and obtained efficiencies [9] [10] [11] [14] [22] [23] [24] [25] [26] of Si tandem solar cells as a function of average external radiative efficiency (ERE) and resistance loss $\left(r_{s}+1 / r_{s h}\right)$, in comparison with those of III-V 3 -junction [6] [26] and 2-junction [22] solar cells. $28.1 \%$ and $33 \%$ efficiencies

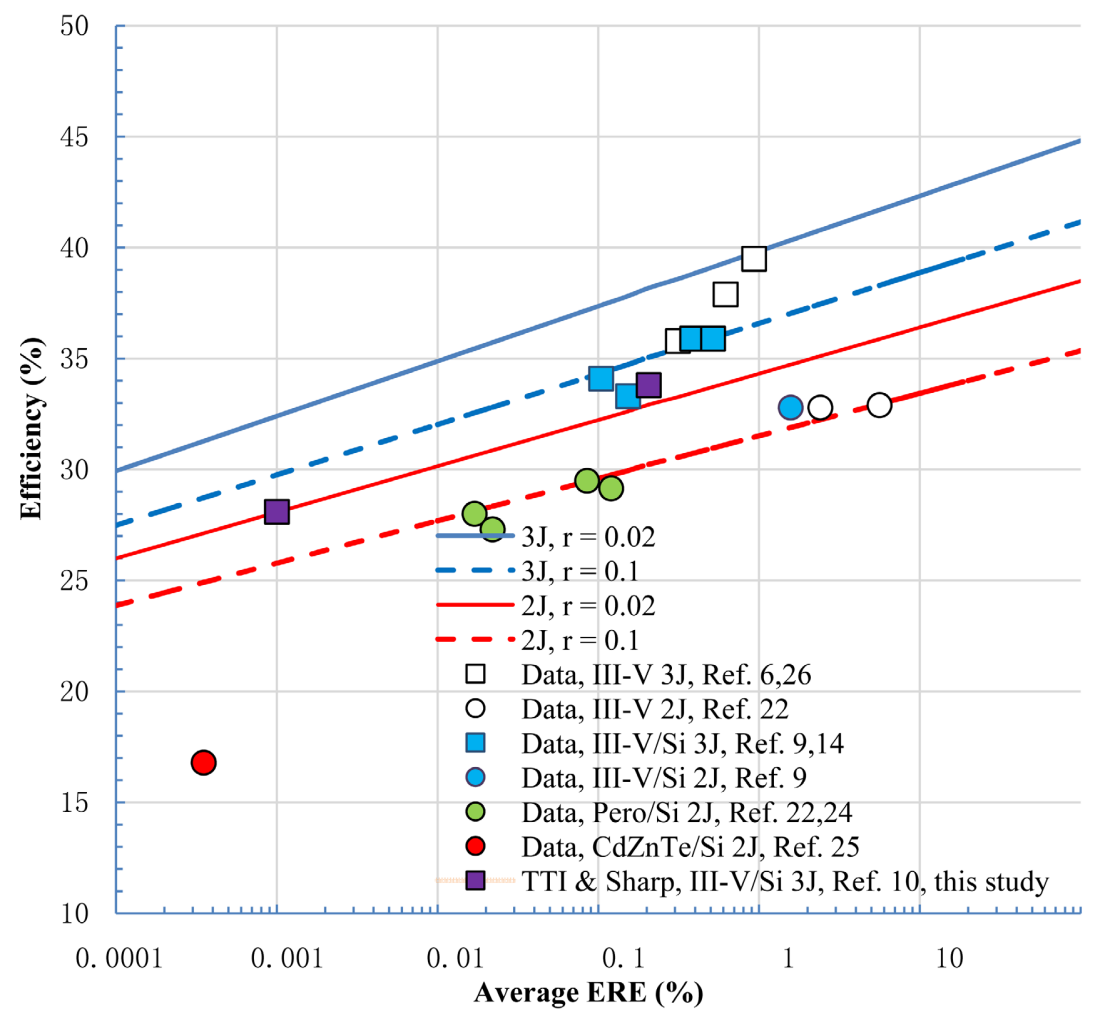

Figure 1. Calculated and obtained efficiencies [9] [10] [11] [14] [22] [23] [24] [25] of Si tandem solar cells as a function of average ERE and resistance loss $\left(r_{s}+1 / r_{s h}\right)$, in comparison with those of III-V 3-junction [6] [26] and 2-junction [22] solar cells. 
have been reported with III-V/Si 3-junction tandem solar cells by authors [10] [11] and 29.5\% efficiency has been demonstrated with perovskite/Si 2-junction tandem solar cell by Oxford PV [22]. Although the state-of-the-art efficiency of III-V/Si 2-juction and 3-junction tandem solar cells are 32.8\% [9] and 35.9\% [9] [14], respectively, the 2-junction and 3-junctions solar cells have potential efficiencies of $36 \%$ and $42 \%$, respectively. Loss analysis of sub-cells is very important in order to realize such a higher efficiency Si tandem solar cell.

\section{Approaches for Realizing High-Efficiency III-V/Si Tandem Solar Cells}

\subsection{Analysis of High-Efficiency Potential of III-V 2-Junction Solar Cells as Upper Sub-Cells of Si Tandem Solar Cells}

Current status of upper III-V 2-junction solar cells was analysed by using the same analytical procedure described in Section 2. Figure 2 shows calculated and observed efficiency values [9] [10] [11] [14] [22] [27] of III-V 2-junction solar cells as a function of average external radiative efficiency (ERE). Although authors' current status of InGaP/GaAs 2-junction solar cells is $28.56 \%, 30.3 \%$ efficiency has been demonstrated with InGaP/GaAs 2-junction solar cell in 1997 by the authors [27]. Around 30\% efficiency III-V 2-junction solar cells are used as upper sub-cells for III-V/Si 3-junction tandem solar cells [11] [14]. Although $32.9 \%$ [22] is the highest efficiency for III-V 2-junction solar cell at present, 36\% will be realized with III-V 2-junction solar cells by improving ERE of more than $10 \%$ and reducing resistance loss as shown in Figure 2.

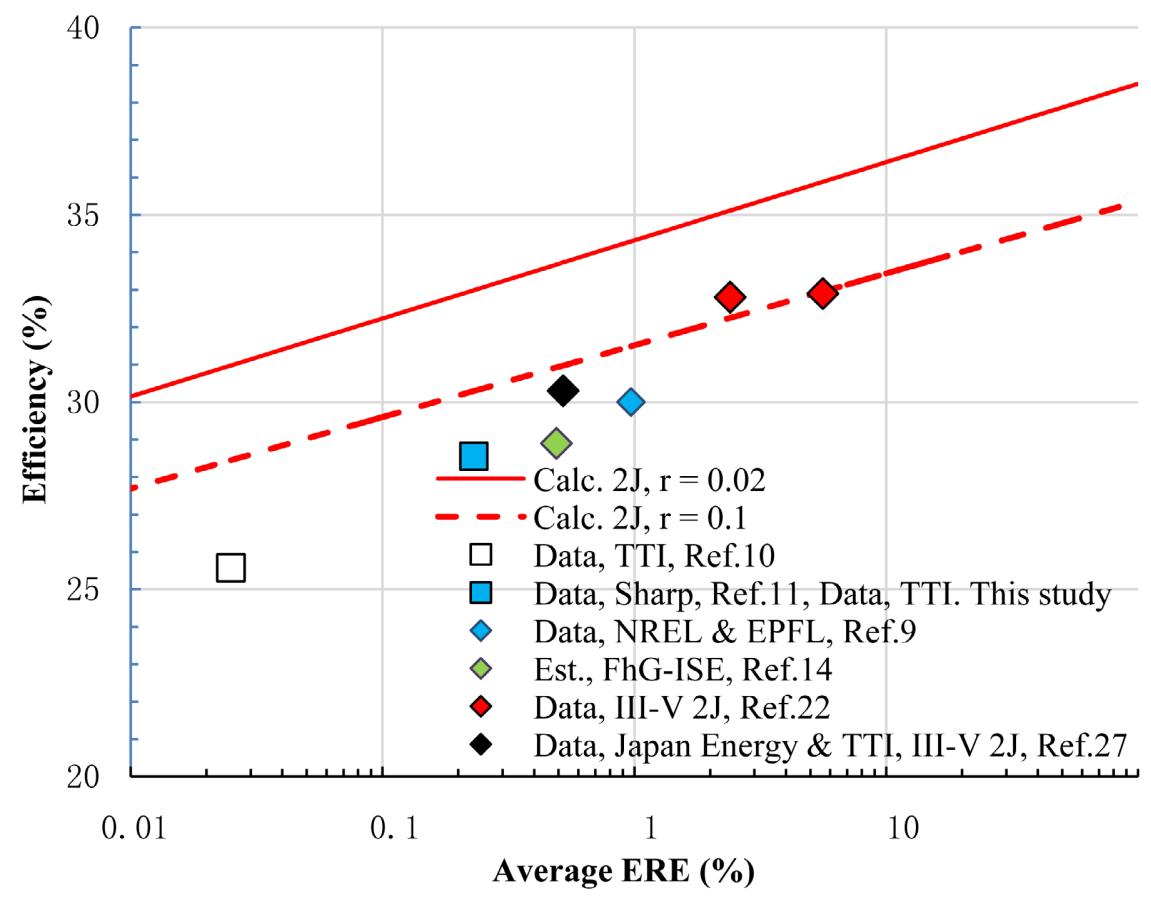

Figure 2. Calculated and observed efficiency values [9] [10] [11] [14] [22] [27] of III-V 2 -junction solar cells as a function of average external radiative efficiency (ERE). 


\subsection{Analysis of High-Efficiency Potential of Si Bottom Solar Cells}

In the Si tandem solar cells, properties of Si bottom cells are thought to be dependent upon bandgap combination and thickness of upper cells and structure and quality of Si bottom cells. The short-circuit current density of sub-cells was estimated from external quantum efficiency $Q(E)$ :

$$
J_{s c}=q \int \phi(E) Q(E) \mathrm{d} E,
$$

where $E$ the photon energy, $\phi(E)$ the photon flux. Figure 3 shows calculated $J_{s c}$ of sub-cells of III-V/Si 3-junction solar cells in comparison with actual $J_{s c}$ values [9] [10] [11] of sub-cells. High $J_{s c}$ of more than $12 \mathrm{~mA} / \mathrm{cm}^{2}$ for Si bottom cells is necessary in order to realize high-efficiency III-V/Si 3-junction tandem cells with an efficiency of more than $37 \%$.

Because the Si bottom solar cells operate under lower illumination intensity condition compared to Si solar cells under 1-sun illumination, illumination intensity properties of solar cells were analyzed in this study. The short-circuit current density $J_{s c}$ is linearly dependent on illumination intensity $I_{I L}$. Illumination intensity properties of open-circuit voltage $V_{o c}$ is given by using $J_{s c}$

$$
V_{o c}=(k T / q) \log \left(J_{s c} / J_{0}+1\right),
$$

where $J_{o}$ is the saturation current density. The steady-state $J-V$ characteristics of a $\mathrm{p}-\mathrm{n}$ junction solar cells are described based on one-diode model [28] [29] [30] [31] [32] as

$$
J=J_{p h}-J_{0}\left[\exp \left\{q\left(V+R_{s} J\right) / n k T\right\}-1\right]-\left(V+R_{s} J\right) / R_{s h},
$$

where $J_{p h}$ is the light generated current density, $J_{0}$ is the reverse saturation current density of the cell, $R_{s}$ is the series resistance and $R_{s h}$ is the shunt resistance. Illumination intensity properties of fill factor FF was analyzed by using Equation (6), $J_{s c} V_{o c} J_{o s} R_{s}$ and $R_{s h}$.

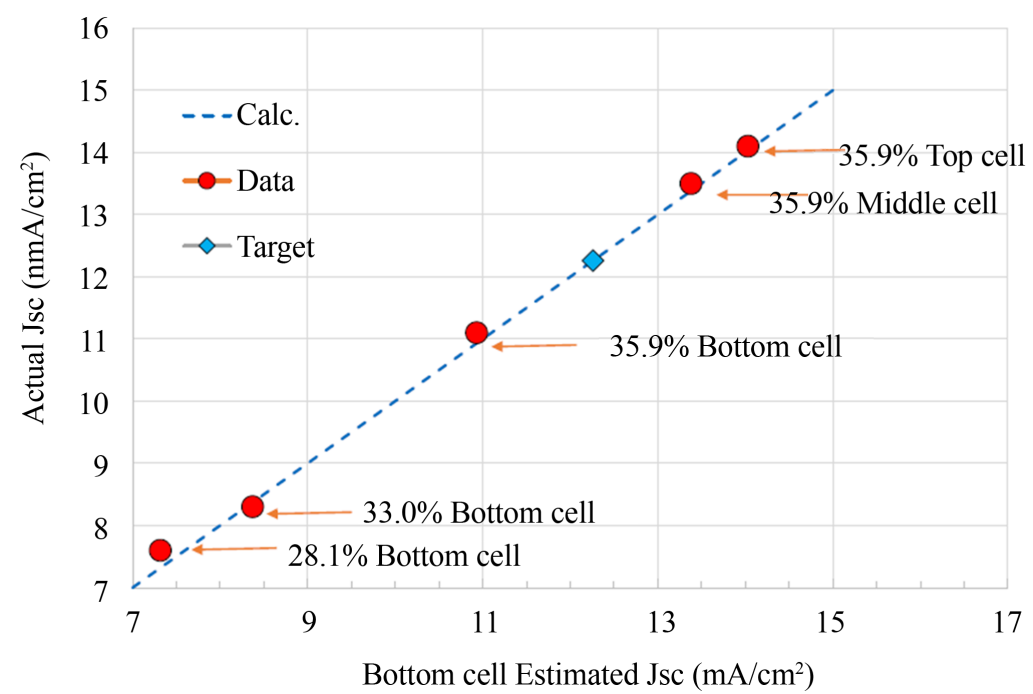

Figure 3. Calculated $J_{s c}$ of sub-cells of III-V/Si 3-junction solar cells in comparison with actual $J_{s c}$ values [9] [10] [11] of sub-cells. 
Illumination intensity properties of single crystalline heterojunction solar cell fabricated in our laboratory were analysed as reported by our previous paper [33]. The fabricated Si hetero-junction (SHJ) solar cell, which is composed of an intrinsic (i-type) a-Si layer and a p-type a-Si layer deposited on a randomly textured phosphorous-doped n-type Czochralski (CZ) crystalline silicon wafer (resistivity $5.2 \Omega \cdot \mathrm{cm}$, thickness $180 \mu \mathrm{m}$ ) to form a p-n heterojunction and i-type and $\mathrm{n}$-type a-Si layers deposited on the opposite side of the wafer to obtain a back surface field structure. Deposition of a-Si layers was made by using plasma chemical vapour deposition. On both sides of the doped a-Si layers, transparent conductive oxide (IWO) layers and metal grid electrodes were fabricated. All of the processes described previously were done at low temperature $\left(<220^{\circ} \mathrm{C}\right)$ to avoid any thermal damage to the components of the cell.

The heterojunction solar cell with an area of $48 \mathrm{~mm} \times 48 \mathrm{~mm}$ shows $22.4 \%$ efficiency $\left(J_{s c}=38.46 \mathrm{~mA} / \mathrm{cm}^{2}, V_{o c}=0.726 \mathrm{~V}, \mathrm{FF}=0.804\right)$ under AM1.5G illumination condition.

Figure 4 shows calculated and measured $J_{s c} V_{o c}$ and $\mathrm{FF}$ of our heterojunction $\mathrm{Si}$ (SHJ) solar cell as a function of illumination intensity. Calculation was made by using Equations (7) and (8). As shown in Figure 4(a), $J_{s c}$ is linearly dependent on illumination intensity. Illumination intensity dependence of $V_{o c}$ shown in Figure 4(b) was calculated by using saturation current density of $J_{o}=3.1 \times$ $10^{-14} \mathrm{~A} / \mathrm{cm}^{2}$. In Figure 4(b), estimated illumination intensity dependence of $V_{o c}$ for Kaneka's $26.3 \%$ efficiency heterojunction back contact (HBC) solar cell in comparison with data [34] for illumination intensity dependence of $V_{o c}$ is also shown. Estimation was made by using $J_{s c}$ of $42.3 \mathrm{~mA} / \mathrm{cm}^{2}$ and $J_{o}$ of $3 \times 10^{-15}$ $\mathrm{A} / \mathrm{cm}^{2}$.

Figure 4(b) suggests that improvements in $J_{s c}$ due to improvement in internal quantum efficiency and due to reduction in optical loss and improvements in $V_{o c}$ by improving $J_{0}$ due to reduction in non-radiative recombination loss are very important for improvement in solar cell properties under low illumination intensity condition.

Illumination intensity dependence of FF shown in Figure 4(c) was calculated by using series resistance $R_{s}$ of $0.05 \Omega \cdot \mathrm{cm}^{2}$, shunt resistance $R_{s h}$ of $700 \Omega \cdot \mathrm{cm}^{2}$ and saturation current density $J_{0}$ of $3 \times 10^{-14} \mathrm{~A} / \mathrm{cm}^{2}$. In Figure 4(c), illumination intensity dependence of FF estimated in the cases of shunt resistance $R_{s h}$ of 2500 $\Omega \cdot \mathrm{cm}^{2}$ and $\infty$ are also shown. In Figure 4(c), estimated illumination intensity dependence of FF for AIST's Si solar cell in comparison with data [35] for illumination intensity dependence of $\mathrm{FF}$ is also shown. Estimation was made by using $R_{s h}$ of $250 \Omega \cdot \mathrm{cm}^{2}$ and $J_{o}$ of $2.5 \times 10^{-12} \mathrm{~A} / \mathrm{cm}^{2}$. Figure $4(\mathrm{c})$ suggests that improvement in FF by improving $J_{o}$ due to reduction in non-radiative recombination loss and by improving shunt resistance $R_{s h}$ is very important for improvement in solar cell properties under low illumination intensity condition.

Figure 5 shows changes in efficiencies of Si bottom solar cells [9] [10] [11] [14] and estimated values of Kaneka's HBC cell [34] analysed as Si bottom cell as a function of short-circuit current density $J_{s c}$ and external radiative efficiency 


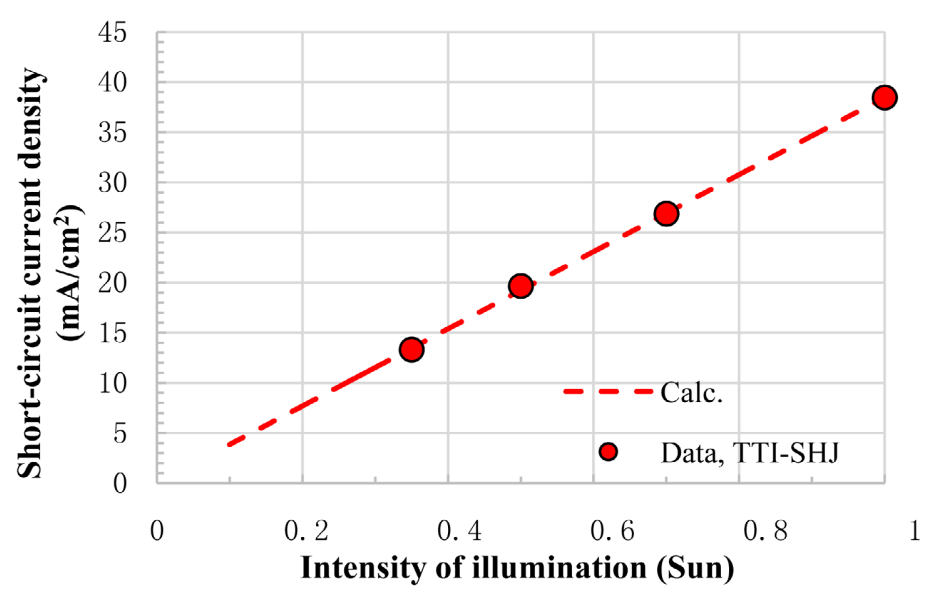

(a)

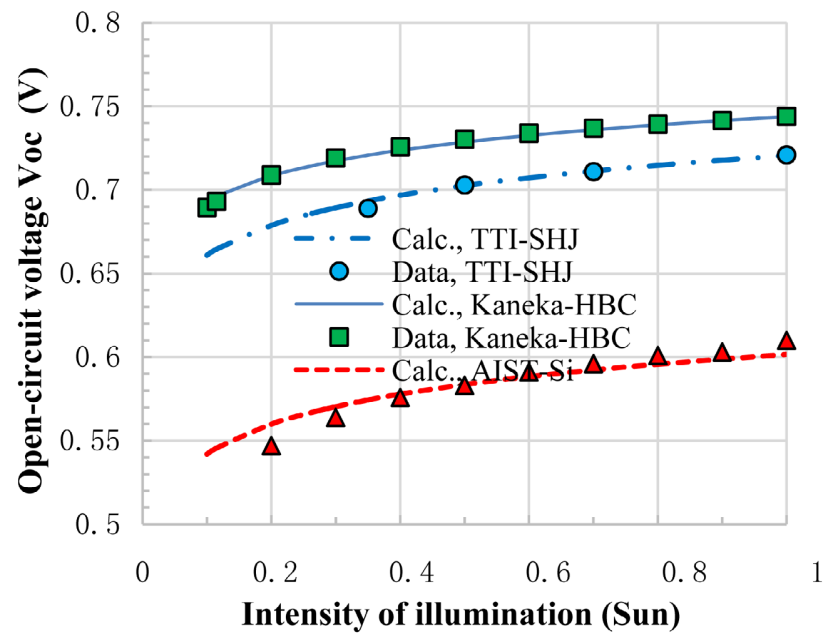

(b)

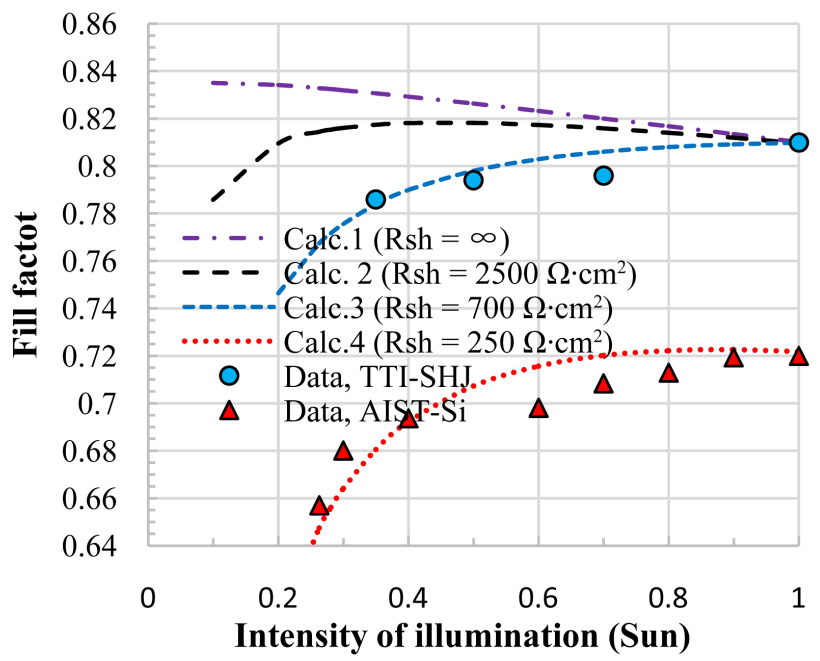

(c)

Figure 4. Calculated and measured $J_{s c}, V_{o c}$ and FF of our heterojunction $\mathrm{Si}(\mathrm{SHJ})$ solar cell as a function of illumination intensity in comparison with those of Kaneka's HBC [34] and AIST's Si [35] solar cells. 


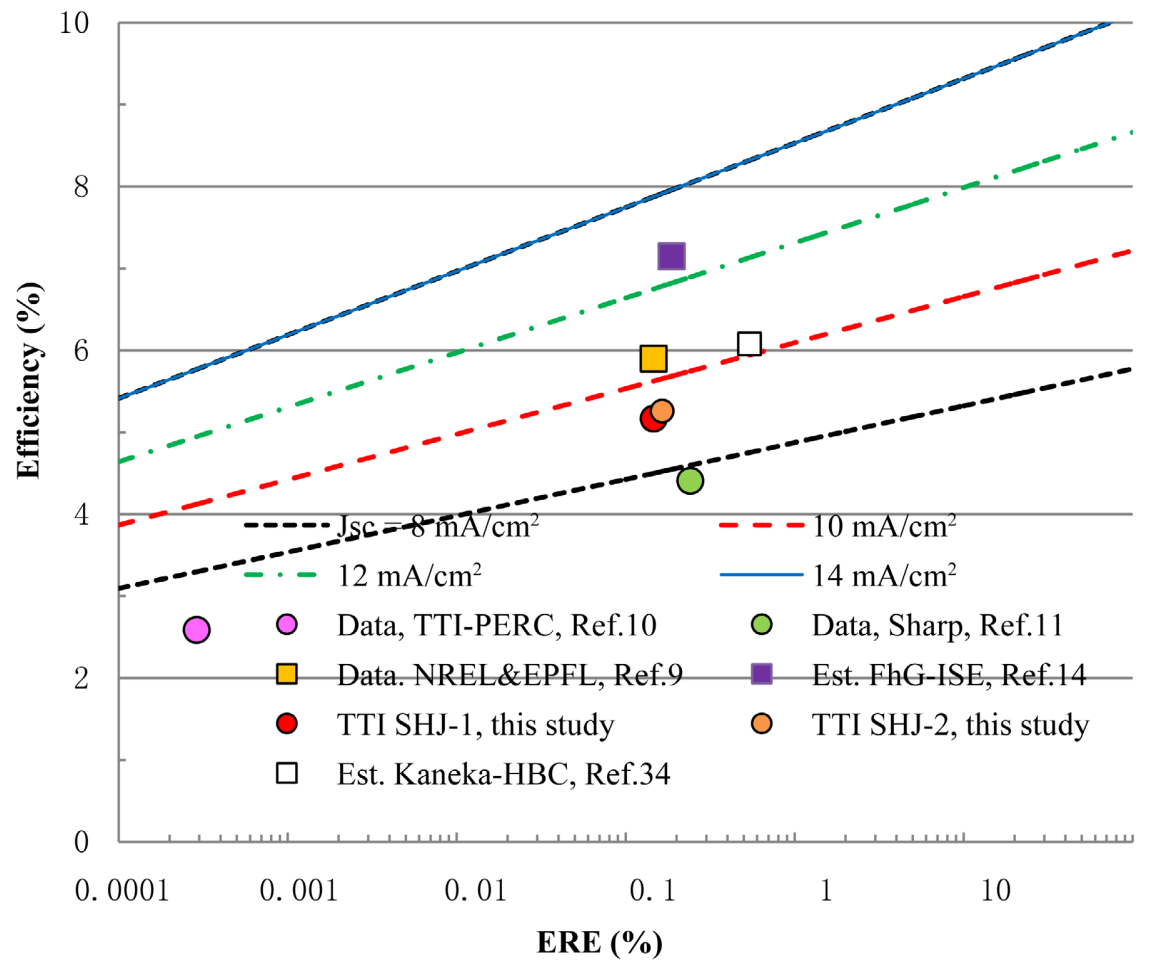

Figure 5. Changes in efficiencies of Si bottom solar cells [9] [10] [11] [14] as a function of short-circuit current density $J_{s c}$ and external radiative efficiency (ERE) in comparison with analytical results.

(ERE) in comparison with analytical results calculated by analytical procedure presented in the Section 2. In this study, Si SHJ solar cell shows $5.26 \%$ efficiency measured under InGaP/GaAs cell filter as shown as TTI SHJ-2 in Figure 5. Because ERE value (0.164\%) of our SHJ bottom solar cell is the similar with those $(0.146 \%$ and $0.187 \%)$ of NREL's SHJ [9] and FhG-ISE's TOPCon (Tunnel Oxide Passivated Contact) [14] Si bottom cells of 35.9\% efficiency III-V/Si 3-junction tandem solar cells, $J_{s c}$ improvement from $9.4-9.8 \mathrm{~mA} / \mathrm{cm}^{2}$ to $11 \mathrm{~mA} / \mathrm{cm}^{2}$ by improving internal quantum efficiency and reducing optical loss is necessary. In addition, optimization of bandgap energy $E_{g}$ of middle cell layer is very effective for increasing $J_{s c}$ of Si bottom cell as demonstrated by FHG-ISE [14]. Higher $J_{s c}$ value of $13 \mathrm{~mA} / \mathrm{cm}^{2}$ of $\mathrm{Si}$ bottom cell has been demonstrated by optimizing $E_{g}$ from $1.42 \mathrm{eV}$ to $1.5 \mathrm{eV}$. Detail of bandgap energy optimization of sub-cells is presented in Section 4. Efficiency improvements of Si bottom cells with 0.5\% and $1 \%$ by improving ERE from about $0.15 \%$ to $1 \%$ and $5 \%$ are expected as shown in Figure 5.

\section{Discussion about Efficiency Improvement of III-V/Si 3-Junction Tandem Solar Cells}

The efficiency of Si tandem solar cells in radiative limit was calculated by assuming ERE of 100\%, optical loss of 5\% and resistance loss of 2\%. Figure 6 shows calculated efficiency [14] [36] in radiative limit of Si tandem solar cells as 


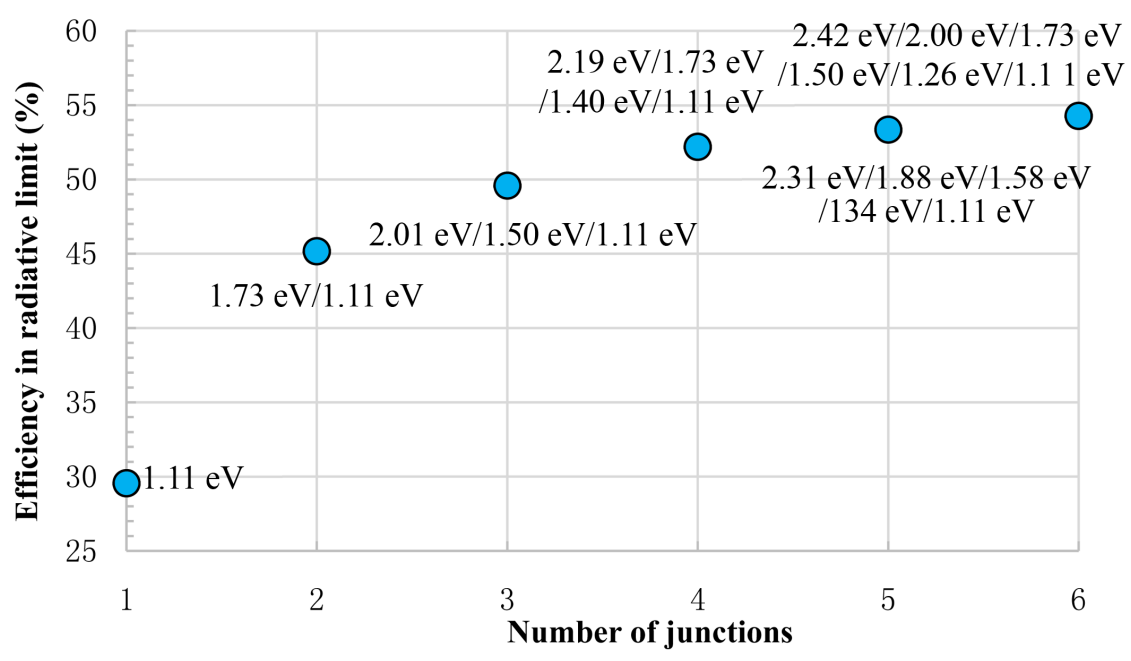

Figure 6. Calculated efficiency in radiative limit of Si tandem solar cells as a function of number of junctions.

a function of number of junctions. Because optimum bandgap energy combination of 2-junction and 3-junction Si tandem solar cells is $1.73 \mathrm{eV} / \mathrm{Si}$ and 2.01 $\mathrm{eV} / 1.50 \mathrm{eV} / \mathrm{Si}$, optimization of bandgap energy for top and middle cells is also necessary. Really, AlGaAs and InGaAsP with an bandgap energy of $1.5 \mathrm{eV}$ have been used as middle cell absorber materials [37] for wafer-bonded III-V/Si 3-junction soar cell. Recently, 35.9\% efficiency has been demonstrated with InGaP/InGaAsP/Si 3-junction solar cell by the FhG-ISE [14].

Figure 7 shows calculated of potential efficiencies of III-V/Si 3-junction tandem solar cells as a function of average external radiative efficiency (ERE) in comparison with realized efficiencies for III-V/Si 3-junction tandem solar cells by authors [10], FhG-ISE [14] and NRE [9] and 39.5\% III-V 3-juncttion solar cell [6]. The current status of efficiencies of our Si bottom cell, upper III-V 2 -junction solar cell and III-V/Si 3-junction tandem solar cell is 5.2\% and $28.6 \%$ [10] and $33.8 \%$. Several ways for improving efficiencies of III-V/Si 3-junction tandem solar cells were considered by analysing potential efficiencies of III-V 2-junction cells shown in Figure 2 and Si bottom cells shown in Figure 5.

As shown in Figure 7, several ways for improvement in efficiencies of Si bottom, upper III-V 2-junction solar cells and III-V/Si 3-junction tandem solar cells are shown:

Way-1: Because 30.3\% efficiency has been demonstrated with InGaP/GaAs 2 -junction solar cell by the authors [27], high-efficiency $35.5 \%(30.3 \%+5.2 \%)$ is expected to be fabricated.

Way-2: By improving $J_{s c}$ from $9.4-9.8 \mathrm{~mA} / \mathrm{cm}^{2}$ to $11 \mathrm{~mA} / \mathrm{cm}^{2}$ of $S i$ bottom cell as a result of improving internal quantum efficiency by using high minority-carrier lifetime wafer and reducing optical loss by effective anti-reflection coating and photon recycling [38], efficiency improvement of Si bottom cell can be improved from $5.2 \%$ to more than $5.9 \%$ and high-efficiency $36.2 \%(30.3 \%+$ $5.9 \%$ ) is expected to be realized. 


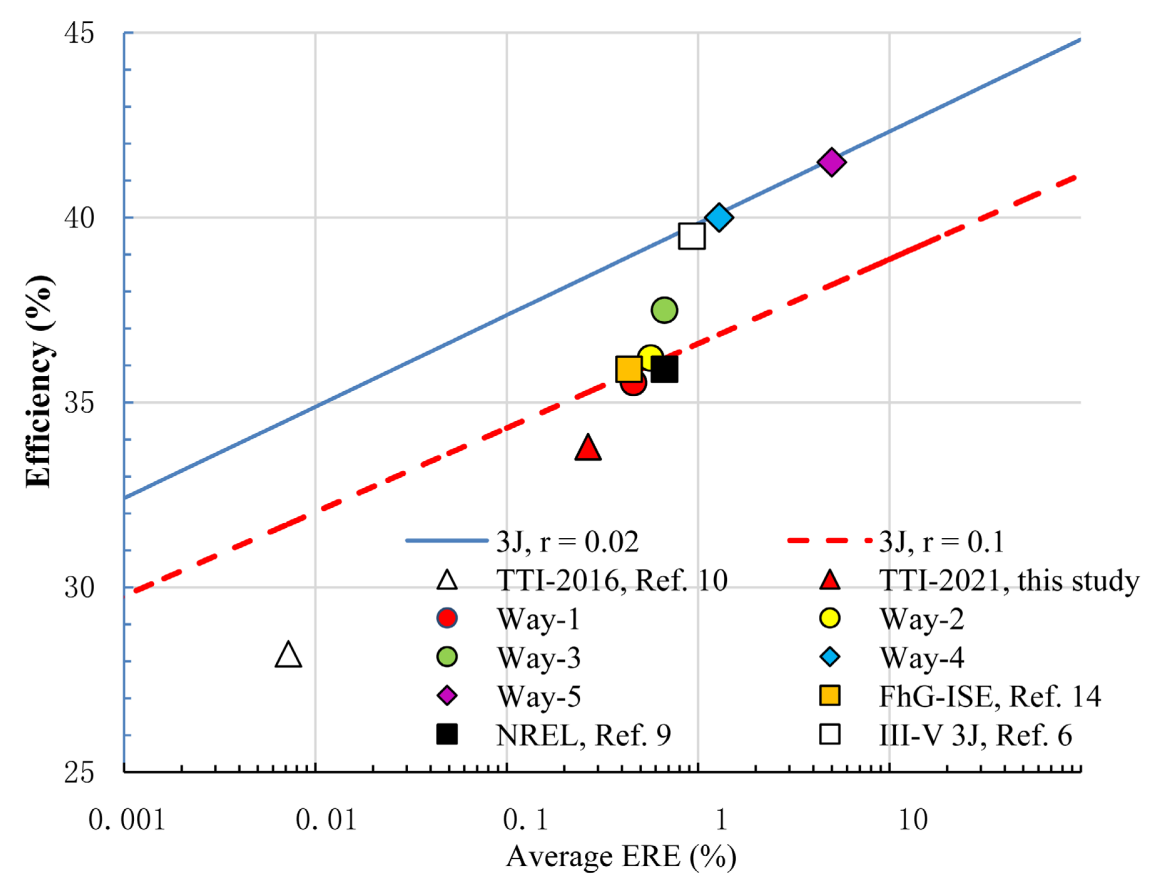

Figure 7. Calculated of potential efficiencies of III-V/Si 3-junction tandem solar cells as a function of average external radiative efficiency (ERE) in comparison with realized efficiencies by authors [10], FhG-ISE [14] and NREL [9] and 39.5\% III-V 3-junction solar cell [6].

In order to realize more than $37 \%$ efficiency, development of Si bottom solar cells with $J_{s c}$ of more than $12 \mathrm{~mA} / \mathrm{cm}^{2}$ is necessary. Effective anti-reflection coating in long wavelength region and photon recycling [38] are thought to be very useful.

Way-3: By using optimum bandgap (1.5 eV) absorber as middle solar cell [14] [37], high $J_{s c}$ with $13.1 \mathrm{~mA} / \mathrm{cm}^{2}$ and high efficiency with $7.2 \%$ of Si bottom cell can be realized as shown in reference 16 and high-efficiency $37.5 \%(30.3 \%+$ 7.2\%) III-V/Si 3-junction tandem solar cell is expected to be realized.

Way-4: By developing high-efficiency $32.8 \%$ with upper III-V 2-junction solar cell as shown in Figure 1, 40\% efficiency $(32.8 \%+7.2 \%)$ III-V/Si 3-junction tandem solar cell is expected to be realized.

For Way-3 and Way-4, optimization of bandgap energies of top and middle cells is thought to be very useful.

Way-5: By improving average ERE with $5 \%$ for III-V/Si 3-junction tandem solar cells as shown in Figure 7, 41.5\% efficiency III-V/Si 3-junction tandem solar cell is expected to be realized.

In order to improve average ERE of III-V/Si 3-junction solar cells, reduction in non-radiative recombination loss of sub-cells by reducing bulk recombination by high quality epitaxial growth and reduction in interface recombination by considering lattice matching of each layers is necessary.

Development of high-efficiency Si tandem solar cell modules with an efficiency of more than $35 \%$ will provide the vehicles longer driving distance with more 
than $30 \mathrm{~km} /$ day average and more than $50 \mathrm{~km} /$ day on a clear day by using solar energy [3]. Although high-efficiency potential of III-V/Si 3-junction tandem solar cells is presented in this paper, there are the other environmental parameters that affect on solar cell module performance and driving distance of PV-powered vehicles. In order to develop high performance VIPV (vehicle-integrated PV), further understanding and decreasing some losses of solar cell modules are necessary. Development of high performance solar cell modules with good temperature coefficient, installation and connection of solar cell modules to reduce partial shading, curved surface, thermal and optical losses, the MPPT (maximum power point tracking) algorism and so forth. Reliability of VIPV under extreme conditions is also very important for developing high performance of PV-powered vehicles.

\section{Summary}

This paper presented analytical results for efficiency potential of Si tandem solar cells and loss analysis of Si bottom cells as well as bandgap energy optimization of sub-cells. The 2-junction and 3-junction Si tandem solar cells have potential efficiencies of $36 \%$ and $42 \%$, respectively. Properties of single-crystalline Si heterojunction solar cell fabricated in this study were analyzed. The current status of efficiencies of our Si bottom cell, upper III-V 2-junction solar cell and III-V/Si 3 -junction tandem solar cell was shown to be $5.2 \%$ and $28.6 \%$ and $33.8 \%$.

In order to attain high-efficiency III-V/Si 3-junction tandem solar cells, necessity of reducing non-recombination, optical and resistance losses of sub-cells was shown. Several ways to improve efficiency of III-V/Si 3-junctuon tandem solar cells were shown in this study. Achievement of $J_{s c}$ of $12 \mathrm{~mA} / \mathrm{cm}^{2}$ for Si bottom cell by improving internal quantum efficiency and reducing optical loss is necessary to realize high-efficiency 3-junction Si tandem solar cells with an efficiency of more than $37 \%$. In addition, this paper suggests that improvements in saturation current density and shunt resistance of Si bottom cells, optimization of bandgap energy of sub-cells are essential for developing high-efficiency $\mathrm{Si}$ tandem solar cells. By developing high-efficiency 32.8\% III-V 2-junction solar cell as upper layer by improving ERE with more than 1\%, high-efficiency III-V/Si 3-junction tandem solar cells with an efficiency of more than $40 \%$ are expected to be realized. Development of high-efficiency III-V/Si tandem solar cell modules with an efficiency of more than $35 \%$ will provide the vehicles with longer driving distance with more than $30 \mathrm{~km} /$ day average and more than 50 $\mathrm{km}$ /day on a clear day by using solar energy.

The effects of the other parameters upon output power generation of vehicle integrated PV modules were also briefly shown. The results provide common information for development of the other Si tandem solar cells such as II-VI/Si, chalcogenide/Si and perovskite/Si tandem solar cells.

\section{Acknowledgements}

The authors would like to express sincere thanks to the NEDO for supporting 
R\&D, to Mr. M. Yamazaki, Mr. K. Fukushima and Mr. M. Iwata, NEDO, Prof. A. Yamamoto, Fukui Univ., Drs. H. Juso, T. Agui and C. Okamoto, Sharp Co., Drs. T. Masuda, K. Okumura and A. Satou, Toyota Motor Co., Profs. K. Nishioka, K, Araki and Y. Ota, Miyazaki Univ. Profs. N. Usami, Y. Kurokawa and K. Gotoh, Nagoya Univ. and Prof. A. Ogura, Meiji Univ. for their fruitful collaboration.

\section{Conflicts of Interest}

The authors declare no conflicts of interest regarding the publication of this paper.

\section{References}

[1] Yamaguchi, M., Masuda, T., Araki, K., Sato, D., Lee, K.-H., Kojima, N., Takamoto, T., Okumura, K., Satou, A., Yamada, K., Nakado, T., Zushi, Y., Yamazaki, M. and Yamada, H. (2020) Role of PV-Powered Vehicles in Low-Carbon Society and Some Approaches of High-Efficiency Solar Cell Modules for Cars. Energy and Power Engineering, 12, 375-395. https://doi.org/10.4236/epe.2020.126023

[2] Yamaguchi, M., Masuda, T., Araki, K., Sato, D., Lee, K.-H., Kojima, N., Takamoto, T., Okumura, K., Satou, A., Yamada, K., Nakado, T., Zushi, Y., Ohshita, Y. and Yamazaki, M. (2021) Development of High-Efficiency and Low-Cost Solar Cells for PV-Powered Vehicles Application. Progress in Photovoltaics, 29, 684-693.

https://doi.org/10.1002/pip.3343

[3] Yamaguchi, M., Masuda, T., Nakado, T., Zushi, Y., Araki, K., Takamoto, T., Okumura, K., Yamada, K., Ota, Y., Nishioka, K., Tanimoto, T., Nakamura, K., Ozaki, R., Kojima, N. and Ohshita, Y. (2021) Importance of Developing Photovoltaics-Powered Vehicles. Energy and Power Engineering, 13, 147-162.

https://doi.org/10.4236/epe.2021.135010

[4] Shockley, W. and Queisser, H.J. (1961) Detailed Balance Limit of Efficiency of p-n Junction Solar Cells. Journal of Applied Physics, 32, Article No. 510. https://doi.org/10.1063/1.1736034

[5] Yamaguchi, M., Dimroth, F., Geisz, J.F. and Ekins-Daukes, N.J. (2021) Multi-Junction Solar Cells Paving the Way for Super High-Efficiency. Journal of Applied Physics, 129, Article ID: 240901. https://doi.org/10.1063/5.0048653

[6] Green, M.A., Dunlop, E.D., Hohl-Ebinger, J., Yoshita, M., Kopidakis, N. and Hao, X. (2021) Solar Cell Efficiency Tables (Version 59). Progress in Photovoltaics, 29, 897-898. https://doi.org/10.1002/pip.3056

[7] Yamaguchi, M., Warabisako, T. and Sugiura, H. (1994) Chemical Beam Epitaxy as a Breakthrough Technology for Photovoltaic Solar Energy Applications. Journal of Crystal Growth, 136, 29-36. https://doi.org/10.1016/0022-0248(94)90379-4

[8] Horowitz, K.A.W., Remo, T., Smith, B. and Ptak, A. (2018) Techno-Economic Analysis and Cost Reduction Roadmap for III-V Solar Cell. NREL Technical Report. 2018. NREL/TP-6A20-72103 November 2018. https://www.nrel.gov/docs/fy19osti/72103.pdf

[9] Essig, S., Allebé, C., Remo, T., Geisz, J.F., Steiner, M.A., Horowitz, K., Barraud, L., Ward, J.S., Schnabel, M., Descoeudres, A., Young, D.L., Woodhouse, M., Despeisse, M., Ballif, C. and Tamboli, A. (2017) Raising the One-Sun Conversion Efficiency of III-V/Si Solar Cells to $32.8 \%$ for Two Junctions and 35.9\% for Three Junctions. Nature Energy, 2, Article No. 17144. https://doi.org/10.1038/nenergy.2017.144 
[10] Yamaguchi, M., Lee, K.-H., Araki, K. and Kojima, N. (2018) A Review of Recent Progress in Heterogeneous Silicon Tandem Solar Cells. Journal of Physics D: Applied Physics, 51, Article ID: 133002. https://doi.org/10.1088/1361-6463/aaaf08

[11] Takamoto, T., Washio, H., Yamaguchi, H., Ijichi, R., Suzuki, Y., Shimada, K., Takahashi, N. and Ooka, S. (2017) IMM Triple-Junction Solar Cells and Module Optimized for Space and Terrestrial Conditions. The 44th IEEE Photovoltaic Specialist Conference, Washington DC, 25-30 June 2017.

https://doi.org/10.1109/PVSC.2017.8366097

[12] Yamaguchi, M., Lee, K.-H., Sato, D., Araki, K., Kojima, N., Takamoto, T., Masuda, T. and Satou, A. (2020) Overview of Si Tandem Solar Cells and Approaches to PV-Powered Vehicle Applications. MRS Advances, 5, 441-450.

https://doi.org/10.1557/adv.2020.66

[13] Yamaguchi, M., Wang, Y.C., Kojima, N., Yamamoto, A. and Ohshita, Y. (2021) Low-Temperature Direct Growth for Low Dislocation Density in III-V on Si towards High-Efficiency III-V/Si Tandem Solar Cells. Japanese Journal of Applied Physics, 60, SBBF14. https://doi.org/10.35848/1347-4065/abde2b

[14] Schygulla, P., Müller, M., Lackner, D., Höhn, O., Hauser, H., Bläsi, B., Predan, F., Benick, J., Hermle, M., Glunz, S.W. and Dimroth, F. (2021) Two-Terminal III-V/Si Triple-Junction Solar Cell with Power Conversion Efficiency of $35.9 \%$ at AM1.5g. Progress in Photovoltaics.

[15] Rau, U. (2007) Reciprocity Relation between Photovoltaic Quantum Efficiency and Electroluminescent Emission of Solar Cells. Physical Review B, 76, Article ID: 085303. https://doi.org/10.1103/PhysRevB.76.085303

[16] Green, M.A. (2012) Radiative Efficiency of State-of-the-Art Photovoltaic Cells. Progress in Photovoltaics, 20, 472-476. https://doi.org/10.1002/pip.1147

[17] Yao, J., Kirchartz, T., Vezie, M.S., Faist, M.A., Gong, W., He, Z., Wu, W.H., Troughion, J., Watson, T., Bryant, D. and Nelson, J. (2015) Quantifying Losses in Open-Circuit Voltage in Solution-Processable Solar Cells. Physical Review Applied, 4, Article ID: 014020. https://doi.org/10.1103/PhysRevApplied.4.014020

[18] Yamaguchi, M., Yamada, H., Katsumata, Y., Lee, K.H., Araki, K. and Kojima, N. (2017) Efficiency Potential and Recent Activities of High-Efficiency Solar Cells. Journal of Materials Research, 32, 3445-3457. https://doi.org/10.1557/jmr.2017.335

[19] Yamaguchi, M., Lee, K.H., Araki, K., Kojima, N., Yamada, H. and Katsumata, Y. (2018) Analysis for Efficiency Potential of High-Efficiency and Next Generation Solar Cells. Progress in Photovoltaics, 26, 543-552. https://doi.org/10.1002/pip.2955

[20] Yamaguchi, M., Zhu, L., Akiyama, A., Kanemitsu, Y., Tampo, H., Shibata, H., Lee, K.H., Araki, K. and Kojima, N. (2018) Analysis of Future Generation Solar Cells and Materials. Japanese Journal of Applied Physics, 57, $04 \mathrm{FS} 03$. https://doi.org/10.7567/JJAP.57.04FS03

[21] Green, M.A. (1998) Solar Cells. UNSW, Kensington.

[22] Green, M.A., Dunlop, E.D., Hohl-Ebinger, J., Yoshita, M., Kopidakis, N. and Hao, X. (2021) Solar Cell Efficiency Tables (Version 58). Progress in Photovoltaics, 29, 657-667. https://doi.org/10.1002/pip.3444

[23] Lackner, D., Höhn, O., Müller, R., Beutel, P., Schygulla, P., Hauser, H., Predan, F., Siefer, G., Schachtner, M., Schön, J., Benick, J., Hermle, M. and Dimroth, F. (2020) Two-Terminal Direct Wafer-Bonded GaInP/AlGaAs//Si Triple-Junction Solar Cell with AM1.g Efficiency of 34.1\%. Solar RRL, 4, Article ID: 2000210. https://doi.org/10.1002/solr.202000210

[24] Al-Ashouri, A., Köhnen, E., Li, B., Magomedov, A., Hempel, H., Caprioglio, P., 
Márquez, J.A., Morales Vilches, A.B., Kasparavicius, E., Smith, J.A., Phung, N., Menzel, D., Grischek, M., Kegelmann, L., Skroblin, D., Gollwitzer, C., Malinauskas, T., Jošt, M., Matič, G., Rech, B., Schlatmann, R., Topič, M., Korte, L., Abate, A., Stannowski, B., Neher, D., Stolterfoht, M., Unold, T., Getautis, V. and Albrecht, S. (2020) Monolithic Perovskite/Silicon Tandem Solar Cell with $>29 \%$ Efficiency by Enhanced Hole Extraction. Science, 370, 1300-1039.

https://doi.org/10.1126/science.abd4016

[25] Carmody, M., Mallick, S., Margetis, J., Kodama, R., Biegala, T., Xu, D., Bechmann, P., Garland, J.W. and Sivananthan, S. (2010) Single-Crystal II-VI on Si Single-Junction and Tandem Solar Cell. Applied Physics Letters, 96, Article ID: 153502. https://doi.org/10.1063/1.3386529

[26] Sasaki, K., Agui, T., Nakaido, K., Takahashi, N., Onitsuka, R. and Takamoto, T. (2013) Development of InGaP/GaAs/InGaAs Inverted Triple Junction Concentrator Solar Cell. AIP Conference Proceedings, 1556, Article No. 22. https://doi.org/10.1063/1.4822190

[27] Takamoto, T., Ikeda, E., Kurita, H., Ohmori, M., Yang, M.-J. and Yamaguchi, M. (1997) Two-Terminal Monolithic $\operatorname{In}_{0.5} \mathrm{Ga}_{0.5} \mathrm{P} / \mathrm{GaAs}$ Tandem Solar Cells with a High Conversion Efficiency of over 30\%. Japanese Journal of Applied Physics, 36, Article No. 6215. https://iopscience.iop.org/article/10.1143/JJAP.36.6215 https://doi.org/10.1143/JJAP.36.6215

[28] Karan, K.R. and Shewchun, J. (1978) A Better Approach to the Evaluation of the Series Resistance of Solar Cells. Solid State Electronics, 22, 193-197. https://doi.org/10.1016/0038-1101(79)90112-6

[29] Agarwal, S.K., Muralidharan, R., Agarwal, A., Tiwary, V.K. and Jain, S.C. (1981) A New Method for the Measurement of Series Resistance of Solar Cells. Journal of Physics D: Applied Physics, 14, Article No. 1643.

https://doi.org/10.1088/0022-3727/14/9/011

[30] Priyanka, M.L. and Singh, S.N. (2007) A New Method for the Measurement of Series and Shunt Resistance of Silicon Solar Cells. Solar Energy Materials and Solar Cells, 91, 137-142. https://doi.org/10.1016/j.solmat.2006.07.008

[31] Khan, F., Singh, S.N. and Husain, M. (2010) Effect of Illumination Intensity on Cell Parameters of a Silicon Solar Cell. Solar Energy Materials and Solar Cells, 94, 1473-1476. https://doi.org/10.1016/j.solmat.2010.03.018

[32] Hishikawa, Y., Doi, T., Yamagoe, K., Ohshima, H., Takenouchi, T. and Yoshita, M. (2018) Voltage-Dependent Temperature Coefficient of the I-V Curves of Crystalline Silicon Photovoltaic Modules. IEEE Journal of Photovoltaics, 8, 48-53. https://doi.org/10.1109/JPHOTOV.2017.2766529

[33] Yamaguchi, M., Ozaki, R., Nakamura, K., Lee, K-H., Kojima, N., Ohshita, Y., Masuda, T., Okumura, K., Satou, A., Nakado, T., Yamada, K., Araki, K., Ota, Y., Nishioka, K., Takamoto, T., Zushi, Y., Tanimoto, T., Thiel, C., Tsakalids, A. and Jager-Wldau, A. (2021) Development of High-Efficiency Solar Cell Modules for Photovoltaics-Powered Vehicles. Solar RRL. https://doi.org/10.1002/solr.202100429

[34] Yoshikawa, K., Kawasaki, H., Yoshida, W., Irie, T., Konishi, K., Nakano, K., Uto, K.T., Adachi, D., Kanematsu, M., Uzu, H. and Yamamoto, K. (2017) Silicon Heterojunction Solar Cell with Interdigitated Back Contacts for a Photo Conversion Efficiency over 26\%. Nature Energy, 21, Article No. 17032. https://doi.org/10.1038/nenergy.2017.32

[35] Hishikawa, Y., Imura, Y., Sekimoto, T. and Oshiro, T. (2002) Irradiance-Dependence and Translation of the I-V Characteristics of Various Kinds of Solar Cells. Transactions IEE Japan, 122-B, Article No. 26. (In Japanese) 
https://www.jstage.jst.go.jp/article/ieejpes1990/122/1/122_1_26/_pdf https://doi.org/10.1541/ieejpes1990.122.1_26

[36] Yamaguchi, M., Tampo, H., H. Shibata, H., Schygulla, P., Dimroth, F., Kojima, N. and Ohshita, Y. (2021) Analysis for Efficiency Potential of II-VI Compound, Chalcopyrite, and Kesterite-Based Tandem Solar Cells. Journal of Materials Research. (To be published)

[37] Schygulla, P., Heinz, F.D., Dimroth, F. and Lackner, D. (2021) Middle Cell Development for Wafer-Bonded III-V//Si Tandem Solar Cells. IEEE Journal of Photovoltaics, 11, 1264-1270. https://doi.org/10.1109/JPHOTOV.2021.3090159

[38] Bläsi, B., Höhn, O., Hauser, H., Tucher, N., Cariou, R., Benick, J., Feldmann, F., Beutel, P., Lackner, D., Siefer, G., Glunz, S.W., Bett, A.W., Dimroth, F. and Hermle, M. (2018) Photonic Structures for III-V//Si Multijunction Solar Cells with Efficiency $>33 \%$. Photonics for Solar Energy Systems, 7, Article ID: 1068803.

https://doi.org/10.1117/12.2307831 